\title{
JEVANY-DUBINA - REVIZNÍ VÝZKUM ZANIKLÉHO STŘEDOVĚKÉHO SÍDLIŠTĚ NA ČERNOKOSTELECKU
}

\author{
MARTIN JANOVSKÝ - JAN HORÁK - TOMÁŠ KLÍR
}

\begin{abstract}
Abstrakt: Předkládaná studie shrnuje výsledky revizního geodetického zaměření, povrchových sběrů a geofyzikálního prĩzkumu sídliště v poloze Dubina, $k$. ú. Jevany, na Černokostelecku. Nově bylo dokumentováno několik drobnějšich povrchových tvarů, např́klad relikty pece v trojdílném domě, a také komunikačni systémy, které provazovaly lokalitu s okolim. Keramika získaná povrchovými sběry umožnila posunout opuštěni lokality do mladšiho horizontu pustnutí na Černokostelecku (druhá polovina 14. století). Sídelní sociální interpretace lokality není jednoznačná. Mohlo se jednat o drobné sídliště složené ze dvou poddanských usedlostí, nebo o dvưr nápravnika. Zemédèlský potenciál zázemí byl velmi nizký, lokalita navic ležela na rozvodi a problém tak představovala absence vydatného a trvalého vodniho zdroje.
\end{abstract}

Klíčová slova: Čechy - Černokostelecko-13.-15. století-geodetické zaměření-geofyzikální měření.

\section{Jevany-Dubina: Revisory research into a deserted medieval settlement in the Černý Kostelec region}

\begin{abstract}
This study sums up the results of a revisory geodetic survey, surface collections and a geophysical survey of a medieval settlement in Dubina, Jevany cadastral zone, in the Černy Kostelec region. Several small surface forms were newly identified, such as the remains of an oven in a three-section house, as well as communication systems connecting the place with its surroundings. The pottery acquired by surface collecting enabled the shifting of the period when the settlement was deserted into the younger desertion horizon in the region (second half of the 14th century). The social interpretation of the location is not clear. It might have been a small settlement consisting of two liege manors, or a homestead of a vassal. The farming potential of the hinterland was very low; in addition, the settlement was located on a watershed, and there was thus a problem with the absence of a permanent source of water.
\end{abstract}

Key words: Bohemia - Černý Kostelec region - 13th-15th centuries - geodetic survey - geophysical measurements.

\section{1 Úvod}

Černokostelecko je předmětem soustavného archeologického zájmu a zdejší výzkum byl navíc těsně spojen s rozvojem moderních metod a poznávacích př́istupů dějin osídlení a archeologie venkovského prostředí (zejména Klápště 1978; 2016; Smetánka 1959; 1961; SmetánkaKlápště 1981; Vařeka 2010; nově Kypta-Nachtmannová-Neustupný 2016). Z toho důvodu jsou terénní relikty velké části zaniklých středověkých lokalit zpravidla velmi dobře zdokumentovány a interpretovány. Jednou ze známých lokalit je i sídliště v poloze Dubina, k. ú. Jevany (okres Praha-východ), jehož relikty ale byly dokumentovány jen elementárním geodetickým způsobem, interpretace zůstala nejistá a zánik byl kladen již do prvního horizontu zániku vsí na Černokostelecku (druhá polovina 13. století; Klápště 1978, 432, 434-435, 452-453).

Revizní výzkum lokality byl řešen v rámci magisterské diplomové práce na Ústavu pro archeologii FF UK (Janovský 2017). Nejprve proběhl topografický rozbor povrchových tvarů a jejich geodetické zaměření (dále T. Klír a geodeti J. Batulka a Zv. Dragoun), výchozím podkladem byl starší situační plán a popis J. Klápště $(1978,432)$. Následně byl vytvořen plán antropogenních povrchových tvarů (ArcGIS), které byly zároveň detailně slovně popsány a interpretovány. Největším přínosem revizního zaměření se stalo doplnění dosavadního plánu lokality o další objekty, o relikty středověkých cest a o detailnější zaměření některých částí reliktů budov. Výzkum dále pokračoval geofyzikálním měřením (Tencer 2017), jehož úkolem bylo přinést informace o přítomnosti otopných zařízení v reliktech budov a testovat přítomnost podpovrchových situací na zdánlivě volných prostranstvích. Součástí výzkumu byly i povrchové sběry v areálu lokality, zejména $v$ místech obnažených vývraty a lidskou destruktivní činností (narušení po hledačích pokladů apod.). V posledním kroku byly analyzovány přírodní podmínky sídliště a jeho hospodářského zázemí. Výzkum hospodářského zázemí je jedním z hlavních témat, kterým se 
výzkumný tým zabývá. Proto je nutné brát tyto části jako základní výzkum, na který se v budoucnu naváže podrobným geochemickým vzorkováním.

Jednotlivé výzkumné kroky jako celek umožnily zpřesnit sociálně-ekonomickou interpretaci sídliště a jeho časové zařazení.

\section{Př́rodní podmínky}

Sídliště Jevany-Dubina je umístěno do rozhraní dvou geologických jednotek. Podloží tvoří drobnozrnná světlá biotická žula středočeského plutonu (sevanský typ) a nevýrazně porfyrická biotická žula stř̌edočeského plutonu, tzv. říčanský typ (Opletal 1993). Geologické rozdíly tedy nejsou nijak kontrastní. Kvartérní sedimenty jsou mapovány především ve vodní nádrži. Písčitohlinité, hlinitopísčité sedimenty a nivní sedimenty jsou lokalizovány ve větší vzdálenosti od lokality.

Hydrogeologické vrty v okolí archeologických lokalit poskytují další informace o geologickém podloží. Pro tyto účely byl vybrán vrt jižně až jihojihovýchodně od lokality (koordináty v S-JTSK Y=717488, X=1059181). V místě vrtu sahá do hloubky 0,2 metru humózní hlína. Na ni navazuje světle hnědé eluvium, které pokračuje do hloubky $0,8 \mathrm{~m}$. V rozmezí hloubek 0,8 až 45 metrů je světle růžová zkatolizovaná žula. Od hloubky 45 metrů do maximální hloubky vrtu, tj. 60 metrů, je světle hnědá pevná žula. Žula je v tomto horizontu částečně prokřemenělá a rozpukaná (Kokošková 2000).

Lokalita je součástí většího geomorfologického celku Jevanské pahorkatiny (Demek-Mackovčin edd. 2014, 223). Tento okrsek tvoří severní část Dobř́íšské pahorkatiny. V Jevanské pahorkatině převládají porfyrické biotitické žuly říčanského typu, méně drobnozrnné biotitické žuly jevanského typu středočeského plutonu. Geomorfologicky je pro oblast charakteristický rozčleněný strukturně-denudační reliéf s žulovými vrchy se skalními tvary zvětrávání a odnosu.

Lokalitu lze charakterizovat jako víceméně plochou, při detailním pohledu je ale zároveň nápadné její citlivé zasazení do mělkého sedla mezi dvěma vrcholy na západě a východě o nadmořských výškách 451 metrů. V severní části lokality (v místě úvozových cest) je patrné mírné klesání k severovýchodu. Nejsevernější část má nadmořskou výšku $436 \mathrm{~m}$; nadmořská výška jižní části lokality a jejího náspu je rovna 447 metrům.

Půdní pokryv v okolí lokality tvoří kambizemě a na severovýchodě pseudogleje (Tomášek 1995). Informace o typech půd byly získány ze tří kopaných sond v okolí lokality (obr. 1).

Oblast Černokostelecka je specifická tím, že náleží jak povodí Labe, tak Sázavy. Pro území v okolí zaniklého středověkého sídliště Jevany-Dubina je prríznačná sít' malých vodních toků, jež utvářely dobré podmínky pro situování středověkých sídelních areálů. Jednotlivá středověká sídliště se však od sebe navzájem odlišovala v životně klíčových hydrologických podmínkách, jak naposled ukázal J. Klápště (2016, 119-134).

Nejvýraznější vodotečí v blízkosti zaniklé středověké vsi v poloze Jevany-Dubina je Jevanský potok, vzdálený přibližně 500 metrů jihozápadně. Samotná lokalita disponovala jen velmi drobnou, bezodtokovou a spíše jen sezónní vodní nádrží. $Z$ hlediska vodního zdroje proto Jevany-Dubina patřily jistě k jedněm z nejhůře vybavených lokalit na Černokostelecku (Klápště 1978, 434; 2016, 131). Pro srovnání můžeme uvést, že sousední stř̌edověká ves v poloze Ve spáleném u Vyžlovky disponovala až čtyřmi poměrně rozsáhlými nádržemi (Klápště 2016, 120-121). I tato ves v pozdním stř̌edověku zanikla, a právě v nedostatečném zásobování vodou je spatřována jedna ze slabin, která $\mathrm{k}$ tomu mohla významně přispět (Klápště 2016, 131).

Velikost vodní nádrže v Jevanech-Dubině odpovídá nárokům jedné nebo dvou poddanských usedlostí. Drobné vodní nádrže byly běžnou součástí středověkých usedlostí, z prostorově nejbližších analogií můžeme uvést nádrže dokumentované $\mathrm{v}$ areálech zaniklých středověkých vsí Kří u Sadské nebo Roudničce pod Plešivcem (Klír 2008, 390; Procházková Korbová 2011; 2011a). 

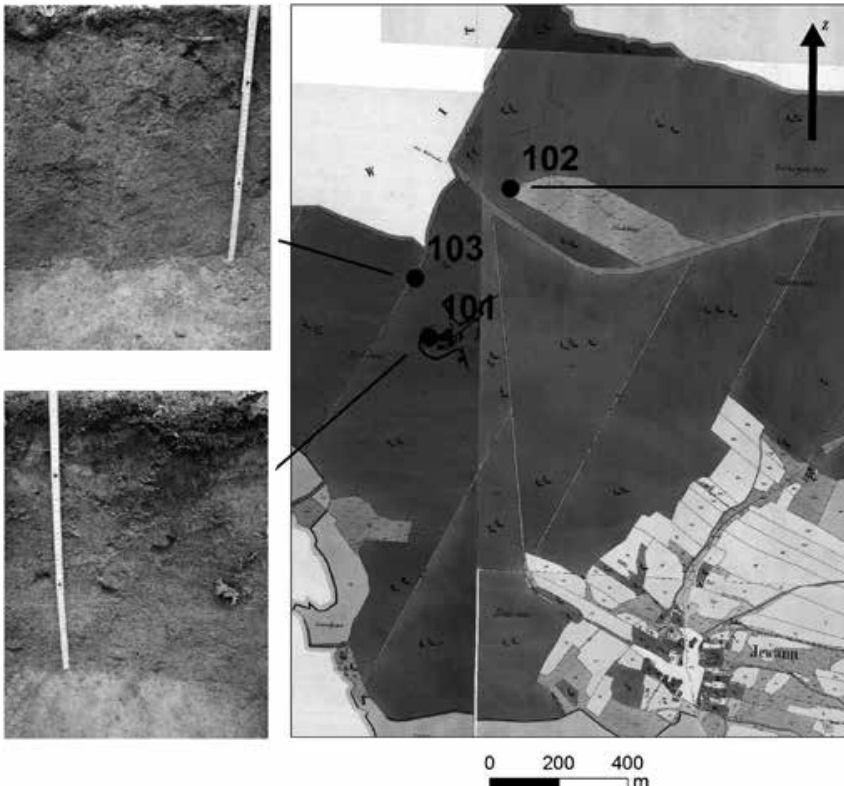

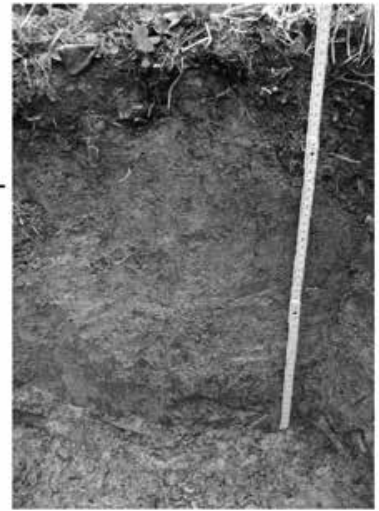

Obr. 1. Tři kopané sondy $v$ intravilánu a extravilánu zkoumané lokality s naznačením přechodu jednotlivých půdních horizontů. Podle geodetického zaměření z roku 2016 provedeného týmem Janovský-Klír et al. a císařského otisku stabilního katastru 1 : 2880 - Jevany 1841 (dostupné z: http://geoportal.cuzk.cz) vypracoval Martin Janovský.

Abb. 1. Drei im Intravillan und Extravillan der untersuchten Fundstätte gelegte Sondierschnitte mit eingezeichnetem Übergang der einzelnen Bodenhorizonte. Nach der geodätischen Vermessung von Janovský-Klír et al. 2016 und einem kaiserlichen Abdruck des Stabilen Katasters 1 : 2880 - Jevany 1841 (abrufbar unter: http://geoportal.cuzk.cz) erstellt von Martin Janovský.

\section{Sídelní kontext a chronologie lokality}

Zaniklé středověké sídliště, jež označujeme podle jeho polohy jako Jevany-Dubina, se nachází v katastru obce Jevan, při severním okraji současné zástavby a v blízkosti místního věžového vodojemu (Klápště 1978, 452-453). Sídliště bylo využíváno nejméně od 13. století do druhé poloviny 14., popřípadě až počátku 15 . století. Spodní časové zakotvení se opírá o výsledky záchranného výzkumu z roku 1972 (Klápště 1978, 423-475), horní o nově nalezenou keramiku v nelegálních výkopech.

J. Klápště pracuje na mikroregionální rovině s termínem lažanský sídelní areál $(2016,131)$. Do tohoto areálu patř́ i Jevany-Dubina. U lokalit v okolí Jevan lze na základě písemných pramenů z období kolem poloviny 14. století vymezit majetkové skupiny dvou šlechtických rodů (obr. 2, srov. Klápště 1978, 464). Ješek z Náchoda, vlastník panství Kostelce nad Černými lesy, disponoval sousední Vyžlovkou a Jevany (RBM VI, 481 č. 796). Lažany a Štíhlice vlastnil rod pánů z Chrástu (RBM VII, 29-30 č. 32). Od roku 1360 je drželi již jako manství (RBM VII, 378 č. 616). Z obrázku 2 plyne, že sídliště Jevany-Dubina s největší pravděpodobností patřilo $\mathrm{k}$ majetkovému komplexu pánů z Náchoda, a původně proto tvořilo součást zázemí královského hradu v Kostelci.

Dataci osídlení vsí v lažanském sídelním areálu stanovenou z písemných pramenů potvrzují i keramické soubory z lokality. Část keramických souborů z Černokostelecka byla publikována, a může tak být oporou při vyhodnocení nově získané keramiky z Jevan-Dubiny. Velké množství keramických zlomků bylo získáno např́iklad povrchovými sběry na Vyžlovce-Ve spáleném (Durdík 1971, 1972), během terénních odkryvů ve Štíhlicích (Smetánka 1959; 1961) či nověji při výzkumu ve Vojkově (Vařeka 2010). Při hodnocení nově zpracovaného menšího souboru z Jevan-Dubiny vycházíme zejména z práce J. Klápště (1978), jenž vypracoval relativní sekvenci keramických souborů z lokalit na Černokostelecku a definoval dva horizonty. První 

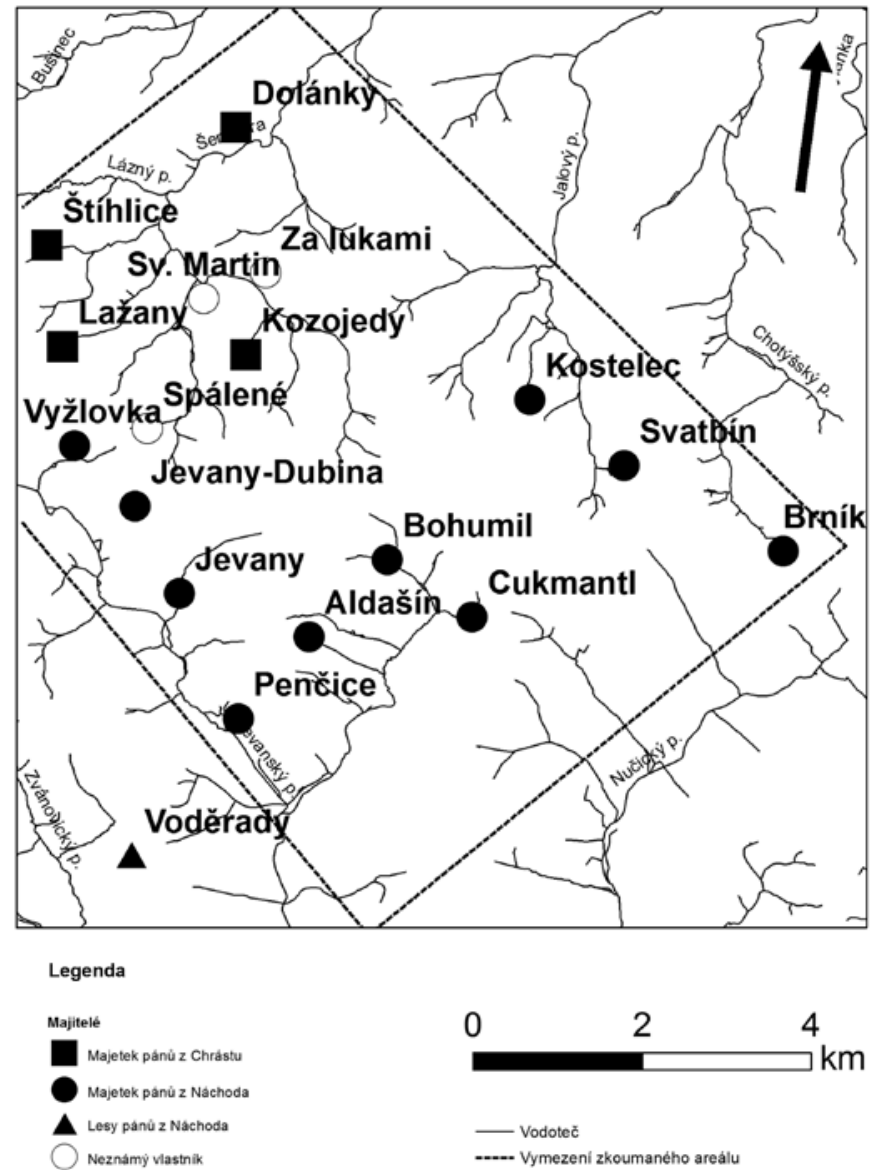

Obr. 2. Lokality na Černokostelecku a jejich majetkové přiřazení. Jevany-Dubina je interpretována jako majetek pánů z Náchoda. Situace v polovině 14. století. Podle WMS ZABAGED® (dostupné z: http://geoportal.cuzk.cz) a Klápště 1978, 464, vypracoval Martin Janovský.

Abb. 2. Fundstätten in der Region Kostelec nad Černými lesy und ihre besitzmäßige Zuordnung. Jevany-Dubina wird interpretiert als Besitz der Herren von Náchod. Situation zur Mitte des 14. Jahrhunderts. Nach WMS ZABAGED ${ }^{\circledR}$ (abrufbar unter: http://geoportal.cuzk.cz) und Klápště 1978, 464, erstellt von Martin Janovský.

nepřekračuje dobu druhé poloviny 13. století a druhý dobu druhé poloviny 14. století (1978, 458-459). Níže je popsán nálezový soubor spadající do prvního horizontu.

Dosavadní datační představa se opírala jen o výzkum objektu $8^{1} \mathrm{z}$ roku 1972 , z nějž pochází na 3757 keramických zlomků (Klápště 1978, 452). Zlomky jsou lepené a obtáčené, část je podobná keramice šedé řady, část pak keramice tzv. hradištní tradice. Výrazně zastoupený je závěrečný horizont, tak jak ho vymezil J. Klápště (1978, 451-455). Výpal zlomků byl tvrdý, materiál jemnější. Výzdoba na nich byla zastoupena rytou šroubovicí, méně vrypy, bílým malováním a vlnicí. Vyskytovalo se zde i vývalkové prohýbání stěn. Z okrajů převládaly varianty s malým vzhůru vytaženým okrajem a okraje rozevřené se zaobleným či kuželovitě seříznutým zakončením (Klápště 1978, 453). 


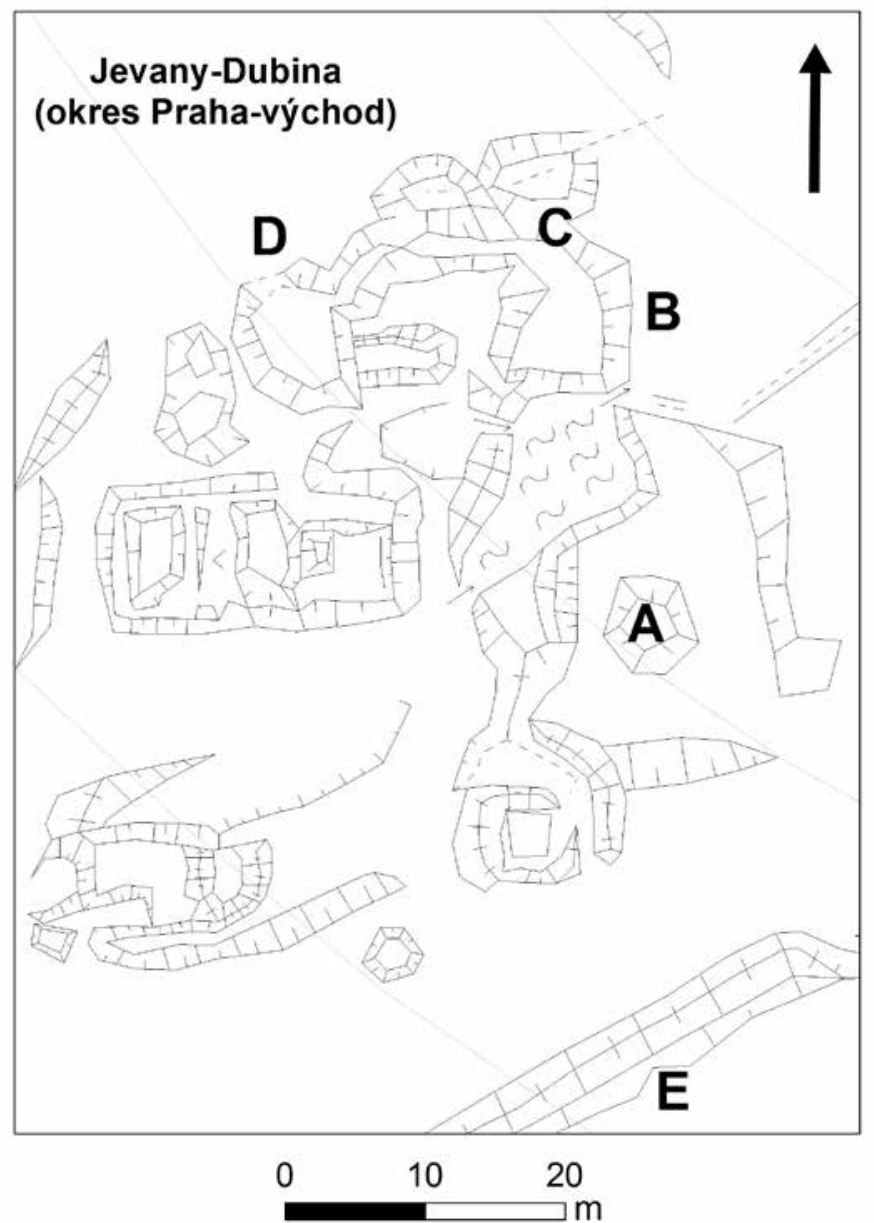

Obr. 3. Místa akumulace keramických zlomků. Podle geodetického zaměření provedeného v roce 2016 týmem JanovskýKlír et al. vypracoval Martin Janovský.

Abb. 3. Anhäufungsstellen von Keramikbruchstücken. Nach der geodätischen Vermessung (2016) von Janovský-Klír et al. erstellt von Martin Janovský.

V současnosti je lokalita porostlá smíšeným lesem, a rozsáhlejší povrchové sběry zde proto nejsou proveditelné. Nicméně v místech vývratů a nelegálních výkopů (místa $\mathrm{C}$ a $\mathrm{E}$, obr. 3) vystupuje na povrch dostatečné množství keramiky na to, aby ji bylo možné vyhodnotit (tab. 1; obr. 4). Podstatné je, že nově byly získány keramické zlomky zařaditelné do závěru celé chronologické řady na Černokostelecku (druhá polovina 14. století). Její charakteristika se opírá o nálezy z výzkumů ve Štíhlicích a na Vyžlovce-Ve spáleném. Svou profilací i výpalem jsou nové nálezy z Jevan-Dubiny převážně zařaditelné do této skupiny (Klápště 1978, 451-452).

Z nově provedených povrchových sběrů na lokalitě pochází 32 nálezů keramických zlomků a jeden kus mazanice (místo A). Z celkového počtu má pouze pět redukční výpal. Zlomky jsou vytočeny či obtáčeny, výrazně převažují těla nádob. Keramika má nejčastěji světle žlutou barvu a její materiál je jemněji proplavený. Pokud je na těle zlomku výzdoba, jedná se o šroubovicovou rýhu, případně plastickou lištu. Okraje jsou ovalené. 


\begin{tabular}{|c|c|c|}
\hline Č́íslo obrázku & Místo nálezu & Popis keramických zlomků \\
\hline $4: 1$ & A & $\begin{array}{l}\text { Okraj. Dovnitř vyhnutý, ovalený, dovnitř mírně vytažený a uvnitř prožlabený, délka } \\
8,6 \mathrm{~cm} \text {, výška } 3,9 \mathrm{~cm} \text {, šriřka } 1,1 \mathrm{~cm} \text {, středně hrubé ostřivo, redukční výpal, stopy po } \\
\text { obtáčení. }\end{array}$ \\
\hline $4: 2$ & A & $\begin{array}{l}\text { Okraj. Dovnitř vyhnutý, ovalený, nahoře vlastní okraj oble zaoblený, délka } 6 \mathrm{~cm} \text {, } \\
\text { výška } 2,3 \mathrm{~cm} \text {, šířka } 0,6 \mathrm{~cm} \text {, středně hrubé ostřivo, oxidační výpal, stopy po obtáčeni }\end{array}$ \\
\hline $4: 3$ & A & $\begin{array}{l}\text { Tělo nádoby. Zlomek je zdobený rytím. Délka } 2,3 \mathrm{~cm} \text {, výška } 2 \mathrm{~cm} \text {, šířka } 0,6 \mathrm{~cm} \text {, } \\
\text { stř̌edně hrubé ostřivo, oxidační výpal, stopy po obtáčení. }\end{array}$ \\
\hline $4: 4$ & A & $\begin{array}{l}\text { Tělo nádoby. Zlomek je zdobený rytou šroubovicí. Délka } 4 \mathrm{~cm} \text {, výška } 3,9 \mathrm{~cm} \text {, šířka } \\
0,7 \mathrm{~cm} \text {, středně hrubé ostřivo, oxidační výpal, stopy po obtáčení nejsou zřetelné. }\end{array}$ \\
\hline $4: 5$ & A & $\begin{array}{l}\text { Okraj. Vně vyhnutý, zdobený je lištou. Délka } 5,9 \mathrm{~cm} \text {, výška } 4 \mathrm{~cm} \text {, šířka } 0,5 \mathrm{~cm} \text {, jemné } \\
\text { ostřivo, oxidační výpal, stopy po obtáčení nejsou zřetelné. }\end{array}$ \\
\hline $4: 6$ & A & $\begin{array}{l}\text { Zlomek plece. Zdobený je lištou. Délka } 3,8 \mathrm{~cm} \text {, výška } 1,1 \mathrm{~cm} \text {, šiřka } 0,6 \mathrm{~cm} \text {, jemné } \\
\text { ostřivo, oxidační výpal, stopy po obtáčení nejsou zřetelné. }\end{array}$ \\
\hline $4: 7$ & B & $\begin{array}{l}\text { Tělo s okrajem výlevky. Délka } 7 \mathrm{~cm} \text {, výška } 6,2 \mathrm{~cm} \text {, šířka } 0,9 \mathrm{~cm} \text {, středně hrubé ostři } \\
\text { vo, redukční výpal, jádro je šedé. }\end{array}$ \\
\hline $4: 8$ & A & $\begin{array}{l}\text { Okraj poklice. Dovnitř vyhnutý, ovalený, vlastní okraj podř́iznutý, délka } 3,6 \mathrm{~cm} \text {, výšs } \\
\text { ka } 4,1 \mathrm{~cm} \text {, šírka } 1,2 \mathrm{~cm} \text {, středně hrubé ostřivo, oxidační výpal, stopy po obtáčení. }\end{array}$ \\
\hline
\end{tabular}

Tab. 1. Přehled vybraných keramických zlomků. Vypracoval Martin Janovský.

Tab. 1. Übersicht ausgewählter Keramikbruchstücke. Erstellt von Martin Janovský.

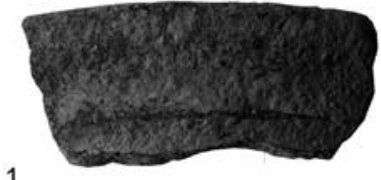

1
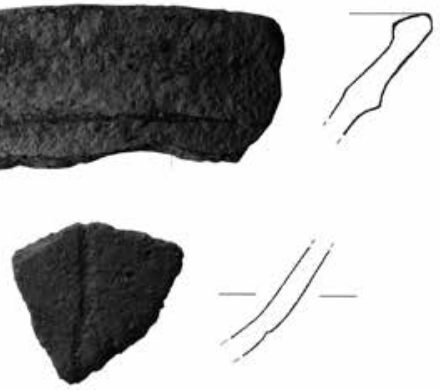

5
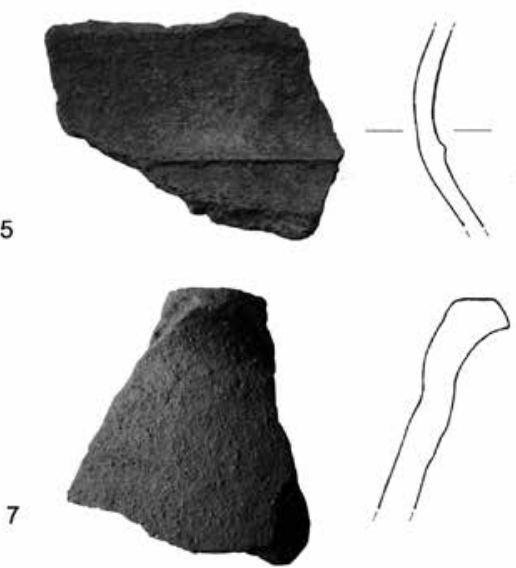

2
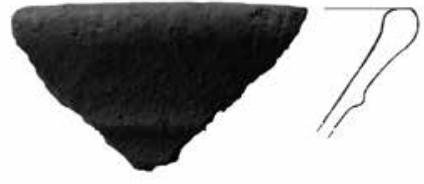

4
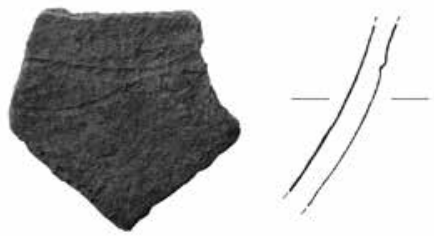

6
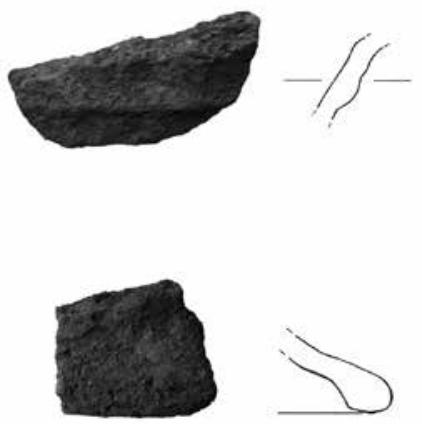

8

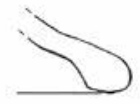

Obr. 4. Tabulka keramických zlomků z lokality Jevany-Dubina. Vypracoval Martin Janovský. Abb. 4. Keramikfragmente von der Fundstätte Jevany-Dubina. Erstellt von Martin Janovský. 
Povrchové sběry z roku 2016 nám umožnily doplnit představu o dataci lokality a lze je shrnout do několika bodů:

1. Lokalita byla osídlena již v prvním horizontu osídlení Černokostelecka, který končí nejpozději ve druhé polovině 13 . století.

2. Existence sídliště je, na základě nově provedených povrchových sběrů, doložena i pro druhý horizont, který výrazněji nepřekračuje dobu druhé poloviny 14. století.

3. Sídliště zaniklo víceméně ve stejné době jako nedaleké vsi Vyžlovka-Ve spáleném, Lažany a Štíhlice.

4. Povrchové relikty je třeba připsat závěrečnému horizontu osídlení. O přítomnosti starších fází může informovat geofyzikální průzkum.

\section{Popis a interpretace reliktů}

Revizní topografický rozbor a geodetické zaměření lokality byly realizovány na jaře 2016, podkladem se stal situační plán J. Klápště $(1978,432)$. Zájmový areál měl rozměry zhruba $200 \times 200 \mathrm{~m}$. Sídlišš bylo umístěno v sedle, na plošině mírně skloněné k severu. Relikty zástavby jsou dnes reprezentovány jak vyvýšenými destrukcemi několika staveb, tak sníženinami a smíšenými tvary (tab. 2). Areál s objekty ohraničuje nízký hřbet interpretovaný jako val, který je rozevřený k severovýchodu. Jeho jihovýchodní konec končí při počátku zaniklé úvozové cesty, jež směřuje k dnešním Jevanům.

Relikty až pěti staveb jsou rozmístěny kolem vodní nádrže, která je dodnes dobře patrná a sezónně naplněná vodou, během zimy a v období sucha nádrž vysychá (obr. 5). Objekty kolem nádrže lze pomyslně ohraničit čtvercem o straně dlouhé $60 \mathrm{~m}$. Kolem nádrže jsou hmotově a plošně nejvýraznější objekty $14,18,20$ a 30, jež lze interpretovat jako pozůstatky budov. Výškově výrazným objektem je objekt 23, jenž je možné považovat jak za zbytek středověké stavby, tak za výsledek lesních prací a recentních úprav terénu. Objekt 18 interpretujeme jako relikt trojdílného domu, v jehož východní části se pravděpodobně dochoval povrchový relikt pece. Společně s objektem 30 jsou u nich patrná nároží, v současnosti odkrytá nelegálními výkopy. V terénu je dále dobře patrné mělké úžlabí mezi objekty 21 a 18, kterým přirozeně na jaře stéká voda do vodní nádrže. Objekt číslo 8 , vysunutý nejdále na západ, sousedí s relikty úvozové cesty. Tento objekt byl zčásti archeologicky zkoumán (Klápště 1978, 434-435, tab. 2) a může sloužit jako analogie k obdobným mohylovitým objektům, které jsou příznačné pro zaniklé vesnice na Černokostelecku (zde také objekt 23). Detailněji má smysl pojednat jen ty objekty (povrchové tvary), které mají význam pro sociálně-ekonomickou interpretaci lokality.

Prvním vybraným objektem je hřbet (2), jenž je na vnější straně doprovázen mělkým př́íkopem. Drobný archeologický řez napříč hřbetem ukázal, že se jedná o násep (val), nikoliv o destrukci zídky (Klápště 1978, 434). Hřbet s př́ikopem lze interpretovat jako pozůstatek ohrazení vydělujícího plochu bezprostředně př́íslušející k sídlišti. Představit si lze ohrazení dvora nebo poddanských dvorů oproti hospodářskému zázemí a svažitému terénu.

Relikty budov kolem vodní nádrže 14, 18, 20 a 30 mají shodnou podélnou orientaci ve směru západ-východ. Obytná funkce je díky reliktu pece prokázána jen v př́ípadě reliktu trojdílného domu 18. Tento dům měl patrně vstup z jihu, po vstupu do síně uprostřed byla napravo umístěna jizba s pecí a nalevo od síně pak komora. Odlišné řešení vstupu lze předpokládat u objektu 14, kde jižnímu vstupu brání svah, vstupovalo se patrně ze severu. Objekty 20 a 30 jsou špatně zachovalé, ale je více než pravděpodobné, že by mohly kopírovat model vstupu z jihu. Objekt 30 je pravděpodobně pozůstatkem druhého trojdílného domu, který doprovázely hospodářské stavby (29 a 31). Objekt 20 tvoří uprostřed výrazná sníženina, jež by mohla být zbytkem podsklepení.

Objekt 23 stojící jihovýchodně v blízkosti vodní nádrže je velmi podobný objektu 8 . U obou není úplně zřejmé, zda se jedná o relikty středověkých budov. Z objektu 23 na povrch vyčnívají lomové kameny (Klápště 1978, 434), přesto je možné, že se jedná o výsledek recentních úprav terénu, v jejichž důsledku byla hlína nahromaděna i s keramickými zlomky a uhlíky, jak tomu 


\begin{tabular}{|c|c|c|c|c|c|c|c|c|}
\hline \multirow{2}{*}{$\begin{array}{l}\text { Číslo } \\
\text { objektu }\end{array}$} & \multirow{2}{*}{$\begin{array}{l}\text { Číslo objektu } \\
\text { dle J. Klápště } \\
1978\end{array}$} & \multirow{2}{*}{$\begin{array}{l}\text { Výšsová } \\
\text { úroveň }\end{array}$} & \multirow[t]{2}{*}{ Тур } & \multirow[t]{2}{*}{ Půdorys } & \multicolumn{2}{|c|}{ Rozměry [m] } & \multirow{2}{*}{$\begin{array}{l}\text { Orientace } \\
\text { delší osy }\end{array}$} & \multirow{2}{*}{$\begin{array}{c}\text { Materiál } \\
\text { vystupující } \\
\text { na povrch }\end{array}$} \\
\hline & & & & & delší osa & kratší osa & & \\
\hline 1 & - & terén & - & - & - & - & - & - \\
\hline 2 & - & vyvýšená & hřbet & nepravidelný & 185 & 4 & - & - \\
\hline $2 \mathrm{a}$ & - & vyvýšená & hřbet & liniový & 36,3 & 3,95 & SSV-JJZ & kámen \\
\hline $2 b$ & - & vyvýšená & hřbet & liniový & 29,9 & 3,9 & SZ-JV & - \\
\hline $2 \mathrm{c}$ & - & vyvýšená & hřbet & liniový & 34,5 & 3,7 & $\mathrm{Z}-\mathrm{V}$ & - \\
\hline $2 \mathrm{~d}$ & - & vyvýšená & hřbet & nepravidelný & 83,4 & 3,4 & SV-JZ & kámen \\
\hline 3 & - & vyvýšená & hřbet & liniový & 41 & - & $\mathrm{Z}-\mathrm{V}$ & - \\
\hline 4 & - & terén & - & - & - & - & - & - \\
\hline 5 & - & terén & - & - & - & - & - & - \\
\hline 6 & - & terén & - & - & - & - & - & - \\
\hline 7 & - & snížená & žlab & nepravidelný & 180,4 & 1,6 & SV-JZ & - \\
\hline 8 & 6 & vyvýšená & kupa & oválný & 14,8 & 10,8 & SSV-JJZ & - \\
\hline 9 & - & vyvýšená & hřbet & liniový & 9,2 & 2,6 & SZ-JV & kámen \\
\hline 10 & - & smíšená & $\begin{array}{l}\text { terénní } \\
\text { svah }\end{array}$ & nepravidelný & 6 & 2,1 & SV-JZ & - \\
\hline $11 \mathrm{a}$ & - & smíšená & žlab & liniový & 39,7 & 2,6 & S-J & kámen \\
\hline $11 \mathrm{~b}$ & - & smíšená & žlab & liniový & 29 & 2,3 & S-J & kámen \\
\hline $11 \mathrm{c}$ & - & smíšená & $\begin{array}{l}\text { terénní } \\
\text { stupeň }\end{array}$ & liniový & 7,8 & 1,4 & S-J & kámen \\
\hline 12 & - & snížená & - & kruhový & 4,2 & 4 & SV-JZ & - \\
\hline 13 & - & snížená & - & čtvercový & 2,8 & 1,9 & SZ-JV & - \\
\hline $14 \mathrm{a}$ & 3 & vyvýšená & - & obdélníkový & 12 & 5,4 & $\mathrm{Z}-\mathrm{V}$ & kámen \\
\hline $14 \mathrm{~b}$ & 3 & vyvýšená & - & čtvercový & 6 & 5,4 & $\mathrm{Z}-\mathrm{V}$ & kámen \\
\hline $14 \mathrm{c}$ & 3 & smíšená & $\begin{array}{l}\text { terénní } \\
\text { stupeň }\end{array}$ & liniový & 23,8 & 1,8 & $\mathrm{Z}-\mathrm{V}$ & - \\
\hline $14 \mathrm{~d}$ & 3 & smíšená & $\begin{array}{l}\text { terénní } \\
\text { stupeň }\end{array}$ & liniový & 17,4 & 0,8 & SV-JZ & - \\
\hline 15 & - & vyvýšená & hřbet & liniový & 7,4 & 2,5 & SV-JZ & - \\
\hline 16 & - & smíšená & $\begin{array}{l}\text { terénní } \\
\text { stupeň }\end{array}$ & liniový & 14,3 & 1,4 & S-J & - \\
\hline 17 & - & vyvýšená & hřbet & liniový & 13,2 & 3 & SSV-JJZ & - \\
\hline $18 \mathrm{a}$ & 2 & smíšená & - & čtvercový & 10,7 & 8,5 & S-J & kámen \\
\hline $18 \mathrm{~b}$ & 2 & smíšená & - & čtvercový & 11,3 & 6 & S-J & kámen \\
\hline $18 \mathrm{c}$ & 2 & smíšená & - & čtvercový & 14,6 & 8,4 & S-J & kámen \\
\hline 19 & - & snížená & $\begin{array}{l}\text { terénní } \\
\text { svah }\end{array}$ & oválný & 6,3 & 5,3 & $\mathrm{Z}-\mathrm{V}$ & kámen \\
\hline 20 & 4 & vyvýšená & hřbet & nepravidelný & 9 & 6,9 & $\mathrm{Z}-\mathrm{V}$ & kámen \\
\hline 21 & - & vyvýšená & hřbet & nepravidelný & 14,2 & 3 & S-J & - \\
\hline $22 \mathrm{a}$ & - & vyvýšená & hřbet & nepravidelný & 6,8 & 2,1 & SZ-JV & \\
\hline $22 b$ & - & smíšená & $\begin{array}{l}\text { terénní } \\
\text { stupeň }\end{array}$ & liniový & 11,5 & 3,3 & $\mathrm{Z}-\mathrm{V}$ & - \\
\hline 23 & 5 & vyvýšená & kupa & oválný & 7,3 & 6 & SSZ-JJV & kámen \\
\hline 24 & - & smíšená & $\begin{array}{l}\text { terénní } \\
\text { stupeň }\end{array}$ & liniový & 22,3 & 2,2 & SSZ-JJV & - \\
\hline
\end{tabular}




\begin{tabular}{|c|c|c|c|c|c|c|c|c|}
\hline \multirow{2}{*}{$\begin{array}{c}\begin{array}{c}\text { Číslo } \\
\text { objektu }\end{array} \\
25\end{array}$} & \multirow{2}{*}{$\begin{array}{c}\begin{array}{c}\text { Číslo objektu } \\
\text { dle J. Klápště } \\
1978\end{array} \\
-\end{array}$} & \multirow{2}{*}{$\begin{array}{l}\text { Výšková } \\
\text { úroveň }\end{array}$} & \multirow{2}{*}{$\begin{array}{c}\text { Typ } \\
-\end{array}$} & \multirow{2}{*}{$\begin{array}{l}\text { Půdorys } \\
\text { oválný }\end{array}$} & \multicolumn{2}{|c|}{ Rozměry [m] } & \multirow{2}{*}{$\begin{array}{c}\begin{array}{c}\text { Orientace } \\
\text { delší osy }\end{array} \\
\text { SV-JZ }\end{array}$} & \multirow{2}{*}{$\begin{array}{c}\begin{array}{c}\text { Materiál } \\
\text { vystupující } \\
\text { na povrch }\end{array} \\
\text { kámen }\end{array}$} \\
\hline & & & & & 17,3 & 8,4 & & \\
\hline 26 & - & smíšená & $\begin{array}{l}\text { terénní } \\
\text { stupeň }\end{array}$ & nepravidelný & 13 & 3 & SZ-JV & - \\
\hline 27 & - & smíšená & $\begin{array}{l}\text { terénní } \\
\text { stupeň }\end{array}$ & nepravidelný & 24 & 1,6 & S-J & - \\
\hline 28 & - & smíšená & $\begin{array}{l}\text { terénní } \\
\text { stupeň }\end{array}$ & nepravidelný & 5,7 & 0,5 & SZ-JV & - \\
\hline 29 & - & snížená & - & obdélníkový & 10,3 & 5 & S-J & - \\
\hline $30 \mathrm{a}$ & 1 & vyvýšená & plošina & nepravidelný & 11,1 & 8,6 & S-J & kámen \\
\hline $30 \mathrm{~b}$ & 1 & smíšená & plošina & obdélníkový & 10,2 & 9,5 & S-J & kámen \\
\hline $30 \mathrm{c}$ & 1 & vyvýšená & plošina & nepravidelný & 12,3 & 9,4 & S-J & kámen \\
\hline $31 \mathrm{a}$ & - & snížená & - & nepravidelný & 11 & 5,6 & SZ-JV & kámen \\
\hline $31 b$ & - & snížená & - & nepravidelný & 8,4 & 6,7 & SV-JZ & kámen \\
\hline 32 & - & smíšená & $\begin{array}{l}\text { terénní } \\
\text { svah }\end{array}$ & liniový & 16,4 & 1,5 & SSZ-JJV & - \\
\hline $33 a$ & - & smíšená & $\begin{array}{l}\text { terénní } \\
\text { stupeň }\end{array}$ & liniový & 56,9 & 1,5 & SSZ-JJV & - \\
\hline $33 b$ & - & smíšená & $\begin{array}{l}\text { terénní } \\
\text { stupeň }\end{array}$ & liniový & 57,5 & 2 & SSZ-JJV & - \\
\hline $34 \mathrm{a}$ & - & vyvýšená & hřbet & liniový & 5 & 1,8 & $\mathrm{Z}-\mathrm{V}$ & - \\
\hline $34 \mathrm{~b}$ & - & vyvýšená & hřbet & oválný & 8,3 & 2 & SZ-JV & - \\
\hline $34 \mathrm{c}$ & - & snížený & - & nepravidelný & 2,2 & 1,6 & S-J & - \\
\hline $34 \mathrm{~d}$ & - & smíšená & $\begin{array}{l}\text { terénní } \\
\text { svah }\end{array}$ & oválný & 2,9 & 1,9 & SZ-JV & - \\
\hline $34 \mathrm{e}$ & - & snížená & - & čtvercový & 2,9 & 2,6 & SV-JZ & - \\
\hline $35 \mathrm{a}$ & - & snížená & - & oválný & 17,8 & 7,7 & SV-JZ & - \\
\hline $35 b$ & - & vyvýšená & hřbet & liniový & 22,1 & 2,6 & $\mathrm{Z}-\mathrm{V}$ & - \\
\hline 36 & - & snížená & - & kruhový & 6,6 & 5,5 & SSV-JJZ & - \\
\hline $37 \mathrm{a}$ & - & smíšená & $\begin{array}{l}\text { terénní } \\
\text { stupeň }\end{array}$ & liniový & 32 & 2 & SSV-JJZ & - \\
\hline $37 \mathrm{~b}$ & - & smíšená & $\begin{array}{l}\text { terénní } \\
\text { stupeň }\end{array}$ & liniový & 29,4 & 3,1 & SSV-JJZ & - \\
\hline 38 & - & vyvýšená & kupa & oválný & 12,2 & 4 & SSV-JJZ & - \\
\hline $39 a$ & - & smíšená & $\begin{array}{l}\text { terénní } \\
\text { stupeň }\end{array}$ & liniový & 12,9 & 0,65 & S-J & - \\
\hline $39 b$ & - & smíšená & $\begin{array}{l}\text { terénní } \\
\text { stupeň }\end{array}$ & liniový & 23,5 & 2 & S-J & - \\
\hline $39 \mathrm{c}$ & - & smíšená & $\begin{array}{l}\text { terénní } \\
\text { stupeň }\end{array}$ & liniový & 12,2 & 0,6 & SSV-JJZ & - \\
\hline $39 \mathrm{~d}$ & - & smíšená & $\begin{array}{l}\text { terénní } \\
\text { stupeň }\end{array}$ & liniový & 16,4 & 0,6 & S-J & - \\
\hline $40 \mathrm{a}$ & - & smíšená & $\begin{array}{l}\text { terénní } \\
\text { stupeň }\end{array}$ & liniový & 13,5 & 0,82 & SSV-JJZ & - \\
\hline $40 \mathrm{~b}$ & - & smíšená & $\begin{array}{l}\text { terénní } \\
\text { stupeň }\end{array}$ & liniový & 10,4 & 0,59 & S-J & - \\
\hline
\end{tabular}

Tab. 2. Souhrnný popis reliktů na lokalitě Jevany-Dubina. Vypracoval Martin Janovský.

Tab. 2. Zusammenfassende Beschreibung der Relikte der Fundstätte Jevany-Dubina. Erstellt von Martin Janovský. 


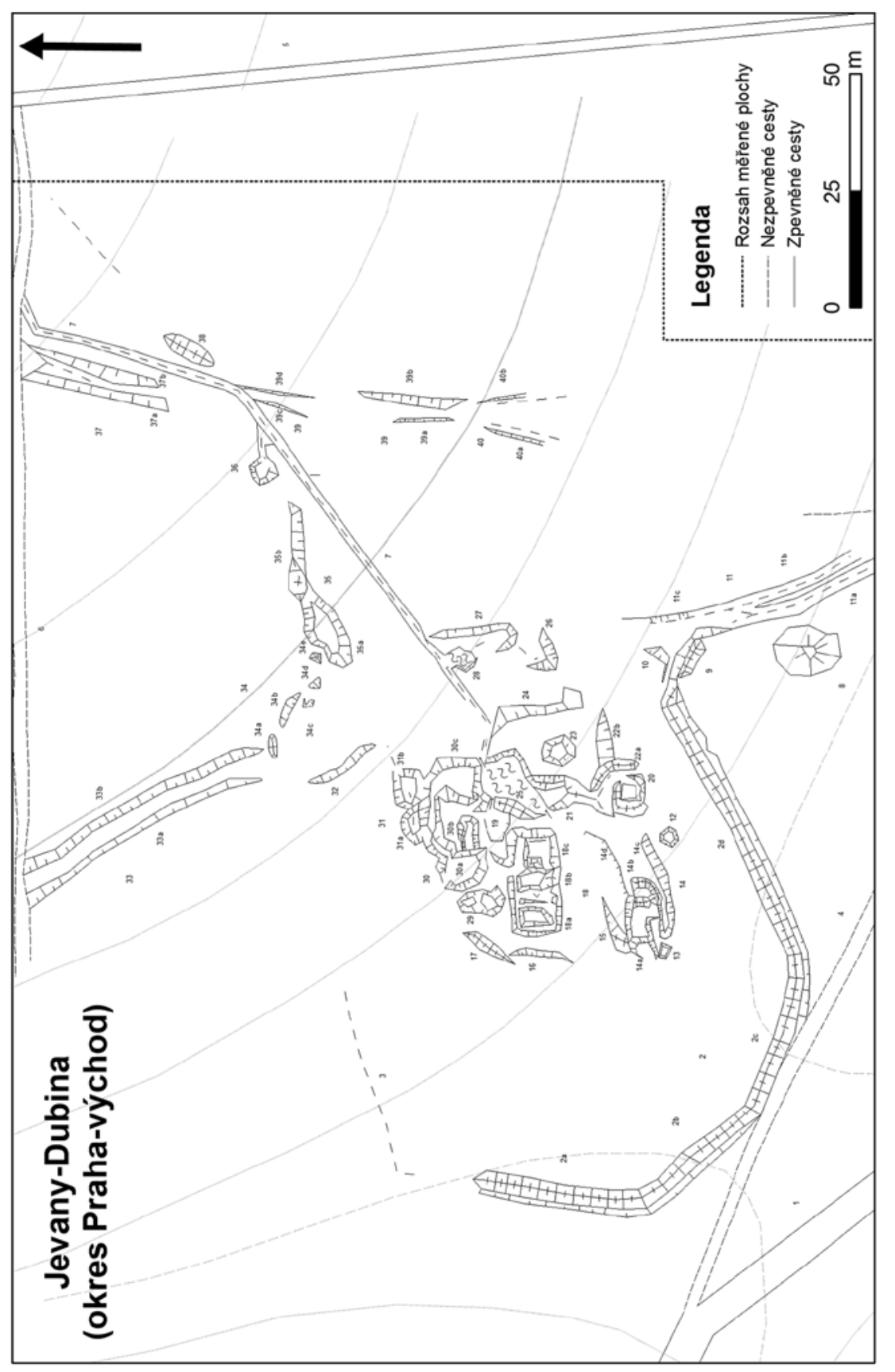

bylo snad i u objektu číslo 8 (Klápště 1978, 434). Této druhé interpretaci nahrává fakt, že na žádný větší objekt v této části sídliště není prostor. Geofyzikální měření v okolí objektu 23 indikuje vícedílnou stavbu, ale její umístění v tomto prostoru není s jistotou rekonstruovatelné.

Na severu lokality se nachází objekty 32 až 36, které mají různé výškové úrovně. Zahloubený objekt 35 je možným reliktem hospodářské stavby, zbylé relikty lze interpretovat jen 
s obtížemi. V objektech 32 a 34d pak vidíme úpravy terénu formou různých zářezů, ty jsou patrné již v okolí nádrže 25. Obtížnou interpretaci některých reliktů komplikuje i skutečnost, že současná podoba lokality je výsledkem několika staletí stavebních aktivit a úprav terénu lesním hospodářstvím. V okolí vodní nádrže se také soustř̌edilo osídlení, které se v průběhu času vyvíjelo.

Důležitým prvkem v terénu je meliorační žlábek, který začíná pod hrází objektu 25 a směřuje k severovýchodu. Na okraji lokality se několikrát lomí a narušuje přirozený průběh úvozové cesty. Po obou stranách žlabu jsou umístěny objekty různých výškových úrovní.

Relikty úvozové cesty běžící podél východní části lokality (objekty 40, 39 a 37) směřují přímo k zaniklé středověké vsi Vyžlovka-Ve spáleném. Cestu proto můžeme s jistotou časově zařadit do doby existence obou lokalit.

\section{Geofyzikální měření}

Geofyzikální měření mělo objasnit zaprvé přítomnost otopného zařízení v objektu 14, a přispět tak k objasnění jeho obytné nebo hospodářské funkce. Zadruhé bylo testováno, zda volné prostranství mezi hřbetem a zástavbou bylo skutečně nezastavěné. Zatřetí měření mělo sledovat i doklady více fází výstavby na lokalitě.

Geomagnetický průzkum lokality provedli pracovníci Ústavu archeologie a muzeologie Filozofické fakulty Masarykovy univerzity v Brně na ploše lehce přesahující jeden hektar. Velkým problémem při interpretaci výsledků měření byla podoba geologického podloží. Lokalita Jevany-Dubina totiž leží na geologickém rozhraní drobnozrnné světlé biotické žuly (jevanský typ) a nevýrazně porfyrické biotické žuly (říčanský typ). Právě rozdílnost geologického podloží nepříznivě ovlivnila výsledky měření. Zvolenou geofyzikální metodou průzkumu byla magnetometrie, která umožňuje rozlišit rozdíly v magnetických hodnotách výplní archeologických objektů.

Průzkum se zaměřil na centrální část lokality. Na jižní straně zkoumané plochy prospekce mírně přesahuje v terénu dobře viditelný hřbet (objekt 2). Některé objekty nebylo možné zkoumat, nebot' v jejich depresích bylo velké množství recentního feromagnetického materiálu (železný odpad, plechovky, kamna atd.; objekty 12, 20, 18c a 30c). Na lokalitě bylo odhaleno sedm magneticky pozitivních anomálií (obr. 6, tab. 3). Lze předpokládat, že jejich vznik byl spojen s antropogenní aktivitou v době využívání lokality i po jejím zániku. Na magnetogramu jsou dále zobrazeny bipolární anomálie s vysokými magnetickými hodnotami. Anomálie mají zejména recentní charakter. V západní části zkoumané plochy byla odhalena bipolární anomálie, která je interpretována jako doklad geologického rozhraní. Anomálie má delší osu orientovanou směrem severovýchod-jihozápad.

\begin{tabular}{|c|l|l|}
\hline Číslo & Popis a umístění & Interpretace \\
\hline G1 & $\begin{array}{l}\text { Anomálie v objektu 17. Umístěna západně od objek- } \\
\text { tu 30 a SZ od objektu 18. }\end{array}$ & $\begin{array}{l}\text { Kamenná konstrukce. Podezdívka či destrukce stavby. } \\
\text { Funkčně také jako ohrazení. }\end{array}$ \\
\hline G2 & $\begin{array}{l}\text { Anomálie v objektu 16. Umístěna západně od } \\
\text { objektu 18. }\end{array}$ & $\begin{array}{l}\text { Kamenná konstrukce. Podezdívka či destrukce stavby. } \\
\text { Funkčně také jako ohrazení. }\end{array}$ \\
\hline G3 & $\begin{array}{l}\text { Bipolární anomálie na nezastavěné ploše mezi } \\
\text { hřbetem a relikty staveb. }\end{array}$ & Pravděpodobně doklad geologického rozhraní. \\
\hline G4 & $\begin{array}{l}\text { Anomálie mezi objekty 22 a 24. Její jádro tvoří } \\
\text { objekt 23. }\end{array}$ & $\begin{array}{l}\text { Kamenná konstrukce o rozměrech } 13 \times 20 \mathrm{~m} \text {. Zřejmě } \\
\text { pozůstatek stavby. }\end{array}$ \\
\hline G5 & Anomálie je součástí objektů 2d a 9. & Kamenná konstrukce. Podezdívka či destrukce stavby. \\
\hline G6 & Hřbet (objekt 2d) & Destrukce valu (ohrazení). \\
\hline G7 & Anomálie kopíruje průběh objektů 14b a 14c. & Kamenná konstrukce. Podezdívka či destrukce stavby. \\
\hline
\end{tabular}

Tab. 3. Geomagnetické struktury viditelné na obrázku 6. Vypracoval Martin Janovský.

Tab. 3. Auf Abbildung 6. sichtbare geomagnetische Strukturen. Erstellt von Martin Janovský. 


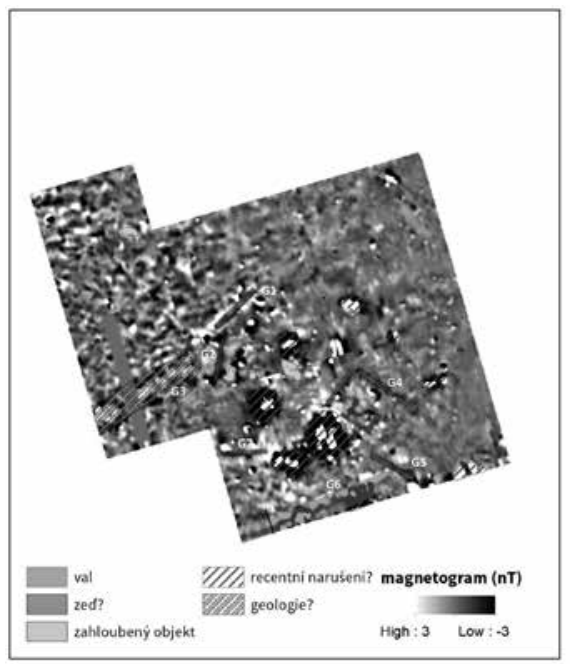

Jevany - Dubina

okres Praha - východ

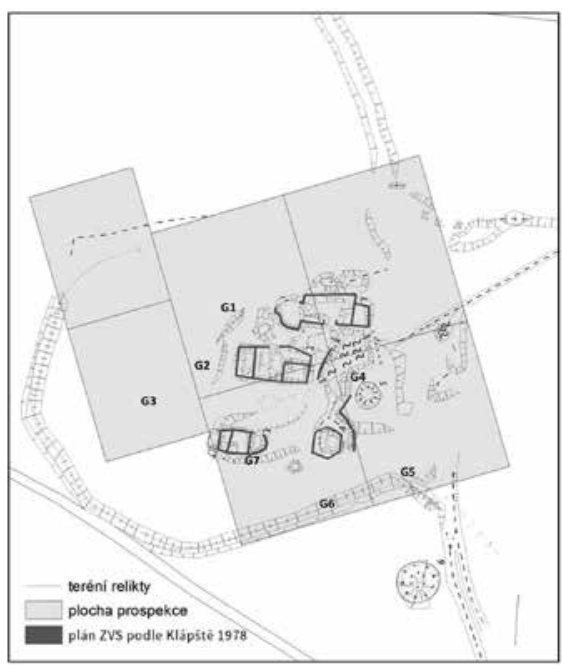

Geomagnetická prospekce $120 \mathrm{~m}$

Obr. 6. Geomagnetická prospekce lokality Jevany-Dubina. Podle plánu vyhotoveného M. Janovským et al. vypracoval Tomáš Tencer.

Abb. 6. Geomagnetische Prospektion der Fundstätte Jevany-Dubina. Nach der Planskizze von M. Janovský et al. erstellt von Tomáš Tencer.

Negativní anomálie byly ztotožněny s relikty kamenných konstrukcí. V okolí objektu 23 byla odhalena kamenná konstrukce, jež není patrná na povrchu. Její obvodové rozměry jsou $13 \times 20 \mathrm{~m}$ a lze předpokládat, že se jedná o pozůstatky stavby. Také se zdá, že je stavba vnitřně členěná. Je nutné zdůraznit, že umístění stavby v této části lokality je zvláštní, svažitost terénu a okolní objekty neposkytují př́liš mnoho prostoru pro její umístění. Lze nicméně předpokládat, že dnes patrný hřbet a terénní stupeň jsou pozůstatkem nějaké dříve stojící stavby (objekty 22a, 22b). Uvažovat tak můžeme o složitějším vývoji sídliště.

Prospekce na severozápadním okraji lokality nedoložila přítomnost reliktů ohrazení tak, jak je interpretováno v terénu (objekt 3). Naopak jižní část náspu je na magnetogramu dobře viditelná i přesto, že u něj nepředpokládáme vnitřní konstrukci.

Velké množství recentního materiálu $\mathrm{v}$ objektech neumožňuje identifikovat přítomnost otopných zařízení. To znesnadňuje interpretaci stavby 14 , u níž tak nelze s jistotou potvrdit původní předpoklad, že se jednalo o hospodářské stavení. Důležitým zjištěním je nicméně potvrzení existence volné nezastavěné plochy na západě lokality. Zde je mezi objekty a náspem plocha, která mohla být využívána například jako zahrada či výběh pro dobytek. Na plánu z geofyzikálního měření jsou dále patrné doklady kamenných konstrukcí, které přiléhají k objektům 14, 18 a 29. Jejich přítomnost lze interpretovat bud' jako podezdívku či destrukci stavby (jako v případě stavby 14), nebo můžeme uvažovat o dalším členění nebo ohrazení lokality (jako v př́ípadě objektů 18 a 29). Podle této rekonstrukce by se tak za zídkami nacházela volná plocha ohrazená náspem. Nelze vyloučit, že zachycené anomálie odráží starší fáze osídlení.

\section{Hospodářské zázemí lokality}

Vymezení potenciálního hospodářského zázemí středověkých sídlišt' umožňuje propojit různé roviny jejich výzkumu, konkrétně znalosti o lokalitě z pohledu archeologie, př́rodního prostředí a sledování jeho variability přímo v terénu. 
K hospodářskému využití (zemědělství, pastva dobytka) se jako nejpříhodnější jeví plocha severovýchodně od sídliště. Je méně svažitá, nicméně pokrytá méně úrodnými pseudoglejemi. Naše poznatky o půdním složení a potenciálu jsme se snažili doplnit pedologickým průzkumem.

Umístění pedologických sond nebylo náhodné. Sonda 101 byla umístěna do volného prostoru v intravilánu vsi západně od reliktů staveb (objekty 14 a 18). Sonda byla vykopána v rovném terénu jehličnatého lesa (obr. 1). Po slabém horizontu $\mathrm{O}$ následoval horizont $\mathrm{Bv}$ o mocnosti 5 až $36 \mathrm{~cm}$ od povrchu, pod ním je horizont $\mathrm{Bv} / \mathrm{C}$ se skeletem. Zrnitost horizontů je jílovitoprachovitá. S jistotou se jedná o kambizem. Na této ploše lze předpokládat (i na základě absence jakýchkoliv reliktů stavební aktivity) plochu vhodnou pro zahradní kultury. Tomu napovídá i pravidelné vymezení vnitřní zástavby na lokalitě.

Využití plochy k zemědělským účelům nelze vyloučit ani jižně od lokality, nicméně se na této ploše dnes nachází moderní zástavba a její studium není možné. Výškové převýšení lokality a Jevanského potoka nemuselo $\mathrm{v}$ minulosti představovat významné omezení pro využívání plochy (ca $60 \mathrm{~m}$ ), limitem byla spíše konkurence se středověkými Jevany.

Sonda 103 byla umístěna severoseverozápadně od lokality, přechod půdních horizontů byl stejný jako u sondy 101, výrazně se sonda lišila jen umístěním v mírném svahu. Ani zde nebyly v terénu pozorovány větší kameny. Je více než pravděpodobné, že celá plocha severně až severovýchodně od lokality byla využívána $\mathrm{k}$ zemědělským účelům.

Severně od cesty vedoucí k Vyžlovce je na otisku stabilního katastru patrná plocha označená jako Moklina (obr. 1). Právě sem jsme umístili sondu 102. V jejím okolí již byly běžné větší kameny, z rostlin převažovaly javory a buky. Po slabém $O$ horizontu následoval v rozmezí 1 až $6 \mathrm{~cm}$ od povrchu A horizont. Pod ním byl zřetelný B horizont v rozmezí 6 až $25 \mathrm{~cm}$ od povrchu. Níže byl B horizont mramorovaný $(\mathrm{Bm})$. Od hloubky $35 \mathrm{~cm}$ byl horizont výrazně písčitý. Sonda byla vykopána na území glejí, charakter krajiny je patrný i z otisku stabilního katastru. Tyto půdy jsou nevhodné pro zemědělskou činnost, lze na nich ale předpokládat louky. Místo mohlo být vhodné pro pastvu dobytka.

Lokalita Jevany-Dubina má jistě zhoršené podmínky pro zemědělské využití, nápadná je nicméně mimořádně vysoká půdní rozrůzněnost. Domníváme se proto, že správně zvolená strategie pro využívání půdy mohla negativní přírodní omezení vyvážit. Na pozadí půdní variability je možné uvažovat o rozmístění polí a přiléhajících luk ve všech směrech mimo jižního a západního. V těchto místech terén prudčeji klesá a lze si představit, že jeho naorávání mohlo vyvolat zvýšenou erozi.

Zemědělskou produkci často omezovaly, nebo dokonce znemožňovaly právě eroze, špatné vodní hospodářství a zavlažování (shrnuje Montgomery 2007). K vyčerpání půd mohlo dojít také dlouhodobým pěstováním nevhodně zvolených plodin. Tyto prŕípady provází lidstvo od vzniku zemědělství a nevyhýbají se žádnému kontinentu (eroze sledovaná od neolitu po současnost Zádorová-Penížek-Šefrna et al. 2013; současný stav eroze půdy a s ním spojená rizika García-Ruiz-Beguería-Lana-Renault et al. 2017). O podobných procesech uvažujeme i u středověkých vsí v Čechách a samozřejmě i u sídliště Jevany-Dubina.

\section{Sociální interpretace}

Na Černokostelecku je zdokumentováno několik zaniklých středověkých vsí, kde bylo možné odhadnout počet usedlostí: Dolánky 9 až 10, Lažany 5, Louňovice 6, Vyžlovka-Ve spáleném 8 (Smetánka-Klápště 1981, 446). Počtem potenciálních usedlostí se řadí Jevany-Dubina $\mathrm{k}$ vůbec nejmenším.

Na základě analogií uvažujeme o dvou variantách sídlištních typů, kterými by středověké sídliště Jevany-Dubina mohlo být $\mathrm{v}$ době, jež předcházela zániku. Zaprvé hospodářský dvůr, popřípadě dvůr jako sídlo nápravníka, s integrovanou poddanskou usedlostí nebo s př́bytkem podsedka. Zadruhé se mohlo jednat o sedliště složené ze dvou, maximálně tří poddanských usedlostí. Základním interpretačním východiskem je prrítomnost minimálně dvou obytných troj- 
dílných domů (18 a 30), dvou hospodářských staveb (14 a 31) a ohrazení (2). K domu 18 patrně náležela hospodářská stavba, dům 30 mohl stát samostatně.

Analogii pro hospodářský dvůr můžeme vidět ve dvoře Rychvald (katastrální území Kozojedy, okres Rakovník), jenž byl dříve mylně považován za tvrz (Kypta a kol. 2012, 552). Areál hospodářského dvora byl vymezen ohrazením, v jehož okolí se dochovalo několik vyvýšených a snížených objektů; najdeme zde i více několikadílných staveb (Kypta a kol. 2012, 553). V těchto bodech si jsou obě lokality nápadně podobné. $\mathrm{O}$ hospodářském dvoře $\mathrm{v}$ Jevanech-Dubině lze uvažovat i díky přítomnosti sklepních prostor (objekt 20), nebot' na dalších lokalitách na Černokostelecku nejsou sklepy doloženy. Sklepy se obvykle vyskytují právě u rychet (krčem) a hospodářských dvorů.

Lokalita Jevany-Dubina je částečně vymezena hřbetem s příkopem. Ohrazení vsí je pro stř̌edověk běžné, nicméně není reliktně tak zřetelně patrné na povrchu. Také na Černokostelecku známe prostorové vymezení areálu jen u hospodářských dvorů (Lažany).

Lokalitu lze hypoteticky ztotožnit se sídlem tzv. nápravníků kosteleckého hradu. Během starší fáze osídlení Černokostelecka lze počítat s jejich funkcí jako služebníků a správců částí královského hvozdu (viz Klápště 1978, 429). Později je mohli převzít i páni z Náchoda. Pro „nápravnickou“ hypotézu svědčí, že lokalita leží na komunikaci spojující Vyžlovku, Jevany a Vyžlovkou-Ve spáleném. Vlastní hospodářský provoz dvora mohli zajišt'ovat podsedci.

Druhou možností je, že v poloze Jevany-Dubina se nacházela malá ves - sedliště. V tom prrípadě můžeme jako modelové příklady uvést několik drobných sídlišt' známých například z Chotěšovska (kraj Plzeňský), která také zanikala častěji než velké vsi (Maur 2013, 60).

Shrneme-li, z ryze sociálního pohledu připadají pro lokalitu dvě varianty:

1. Stály zde dvě poddanské usedlosti, tvořené dvěma trojdílnými obytnými domy (18 a 30$)$ a doprovázené hospodářskými stavbami.

2. Objekt 30 byl centrální obytnou budovou a sídlem nápravníků. Stavby kolem něj tvořily hospodářské zázemí a zahrnovaly i obydlí podsedka/ů, popřípadě chalupnickou usedlost (18).

Za současného stavu poznání se jako pravděpodobnější jeví druhá varianta, a to vzhledem k výraznému prostorovému vymezení areálu a dokladu sklepních prostor.

\section{Závěr}

Sídliště při okraji dnešních Jevan (okres Praha-východ) v poloze Dubina je dlouhodobým předmětem archeologického a sídelně-historického zájmu. $\mathrm{V}$ jeho areálu byly již $\mathrm{v} 70$. letech 20. století provedeny zjištovací a ověřovací archeologické výzkumy a také geodetická zaměření, na něž v této studii navazujeme. Nově rešíme otázky spojené se zemědělským využitím půdy, variabilitou př́rodního prostř́edí a dopadem lidské činnosti.

Výzkum lokality Jevany-Dubina začal revizním geodeticko-topografickým průzkumem a zaměřením lokality. Nově byla získána představa o terénních reliktech situovaných mimo intravilán a o průběhu úvozových cest. Na geodetické zaměření navázal geofyzikální průzkum. Měření magnetometrem indikuje několik fází osídlení a možnou přítomnost vícedílné stavby. V západní části lokality geofyzikální měření potvrdilo variantu, že se zde skutečně vždy nacházelo volné prostranství. Můžeme také uvažovat o zahradě nebo prostoru pro dobytek apod. Hřbet s př́ikopem, který lokalitu ohraničuje z jihu až západu, je patrně dokladem náspu s možným dřevěným plotem. Ohrazení mohlo sloužit i jako ochrana před erozí a splachem, nebot' sídliště je umístěno ve svahu spadajícím k severu. Přítomnost sklepních prostor, hřbetu s př́ikopem a uspořádání staveb umožňují interpretovat lokalitu nejspíše jako nápravnický dvůr s podsedky nebo poddanskou usedlostí. Vyloučit ale nelze ani variantu, že sídliště tvořily dvě poddanské usedlosti.

Povrchové sběry na lokalitě umožnily vložit její opuštění do období kolem přelomu 14. a 15. století, dosud byla předpokládána již druhá polovina 13. století. Alarmující je fakt, že dochází k nelegálním zásahům, které tuto památkově unikátní lokalitu dlouhodobě ničí. 
Otázkou je, do jaké míry je výpověd' získaná výzkumem zaniklých vsí reprezentativní pro středověké osídlení jako celek. Drtivá většina středověkých vsí nezanikla, ale přetrvala dodnes, i když někdy ve značně transformované podobě. Zaniklé vsi z pozdně stř̌edověkého období informují převážně o osídlení na okraji zemědělských možností neboli o mezích tehdejšího ekonomického systému.

Jevany-Dubina disponovala omezeným zdrojem vody, který mohl značně kolísat. Půdní vlastnosti v jejím okolí také nebyly příznivé. Špatná bonita půdy se promítá i do jejího současného využívání. Nevhodné a př́iliš intenzivní zemědělské obdělávání mohlo způsobit vyčerpání půd a mohlo vést k jejich postupné degradaci. Sídliště Jevany-Dubina zaniklo nejpozději v průběhu 15. století a osídlení přetrvalo jen při Jevanském potoku, kde mělo lepší podmínky pro hospodářskou činnost (dnešní Jevany).

Studium hospodářského zázemí lokality zahrnuje geochemický výzkum. V budoucnu plánujeme rozsáhlejší půdní vzorkování jak ve volném ohrazeném prostranství, tak v blízkém okolí lokality. Hodláme sledovat rozdíly v gradientu, který se bude měnit v závislosti na vzdálenosti od lokality. Za průzkum by stálo i poznání geochemického vztahu jednotlivých objektů (úvozová cesta a objekt 8). Taktéž bude zajímavé se zaměřit na geochemické anomálie v okolí pece v domě 18.

Tento výstup vznikl v rámci projektu „Kulturní techniky: materialita, medialita a imaginace“, podprojektu „Středověká ves a její př́írodní prostředí“. Mezioborový výzkum zaniklých vsí v zázemí Prahy řešeného na Filozofické fakultě Univerzity Karlovy z prostředků Specifického vysokoškolského výzkumu na rok 2018 (M. Janovský, J. Horák). Dále byl podpořen grantem GA ČR číslo 16-20763S „Krajina stř̌edověké Prahy / The Landscape of Medieval Prague“ (T. Klír).

Autoři děkují pánům Jaroslavu Batulkovi a Zvonimíru Dragounovi za pomoc při geodetickém zaměření lokality a panu prof. Janu Klápště za průběžné konzultace.

\section{Literatura}

Císařský povinný otisk stabilního katastru 1:2 880 - Čechy, mapový list Jevany 1841. Dostupné z http:// geoportal.cuzk.cz, cit. 3. 4. 2017. DEMEK, J.-MACKOVČIN, P., edd., 2014: Zeměpisný lexikon ČR. Hory a nížiny I. Brno.

DURDÍK, T., 1971: Zaniklá středověká vesnice v katastru obce Vyžlovky - Die mittelalterliche Wüstung im Gemeindegrund der Gemeinde Vyžlovka, AR XXIII, 219-222.

- 1972: Vyžlovka, o. Kolín, BZO 1969, 174-188.

GARCÍA-RUIZ, J. M. et al., 2017: García-Ruiz, J. M.-Beguería, S.-Lana-Renault, N.-Nadal-Romero, E.Cerdà, A., Ongoing and emerging questions in water erosion studies, Land Degradation \& Development 28, 5-21. https://doi.org/10.1002/1dr.2641

JANOVSKÝ, M., 2017: Středověká ves a její př́írodní prostředí. Modelové příklady (8.-15. století) - Medieval village and its natural environment. Model studies (8th-15th century). Rukopis diplomové práce, FF UK Praha.

KLÁPŠTĚ, J., 1978: Středověké osídlení Černokostelecka - Die mittelalterliche Besiedlung im Raum von Kostelec nad Černými Lesy, PA LXIX, 423-475.

- 2016: Hospodaření s vodou ve středověké vsi Ve spáleném u Vyžlovky na Černokostelecku - Water management in the medieval village Ve spáleném near Vyžlovka in the Kostelec-nad-Černými-lesy region, AR LXVIII, 119-134.

KLÍR, T., 2008: Osídlení zemědělsky marginálních půd v mladším středověku a raném novověku - Besiedlung und landwirtschaftliche Nutzung marginaler Böden im späten Mittelalter und der frühen Neuzeit The settlements and agriculture of the margins in the later middle age and early new age. Dissertationes Archaeologicae Brunenses/Pragensesque 5. Praha.

KOKOŠKOVÁ, L., 2000: Jevany, průzkumný hydrogeologický vrt J - 1. Rukopis uložený v archivu České geologické služby v Praze - Kostelní.

KRENZLIN, A., 1952: Dorf, Feld und Wirtschaft im Gebiet der großen Täler und Platten östlich der Elbe. Forschungen zur deutschen Landeskunde 70. Remagen. 
KYPTA, J. a kol., 2012: Kypta, J.-Laval, F.-Neustupný, Z.-Šimůnek, R., Osamocený dvůr s opevněným sídlem v pozdním středověku: Rychvald u Dřevíče (okr. Rakovník) a jeho analogie - An isolated Late Middle Ages farmyard with a fortified residence: Rychvald near Dřevíč (Central Bohemia) and its analogies, AR LXIV, 549-570.

KYPTA, J.-NACHTMANNOVÁ, A.-NEUSTUPNÝ, Z., 2016: Zaniklá středověká a raně novověká vesnice Janovice na Černokostelecku - Die mittelalterliche und frühneuzeitliche Dorfwüstung Janovice in der Umgebung von Kostelec nad Černými lesy, PSČ 30, č. 2, 52-58.

MAUR, E., 2013: Pustnutí vsí na Plzeňsku za pozdně středověké agrární deprese - Dilapidation of villages in Pilsen region during the late medieval agrarian depression. In: Tenkrát na západě (Čech). Kapitoly z dějin kultury a každodennosti Plzně a Plzeňského kraje, 49-66. Plzeň.

MONTGOMERY, D. R., 2007: Dirt. The Erosion of Civilization. Berkeley.

OPLETAL, M., 1993: Geologická mapa ČR. List 13-31 (̌̌íčany), 1 : 50 000. Český geologický ústav. Praha.

PROCHÁZKOVÁ KORBOVÁ, L., 2011: Zaniklá středověká vesnice v poloze „Mořina“ u Běštína - The Deserted Medieval Village in the „Mořina“ Locality near Běštín, Studia Mediaevalia Pragensia 10/1, 25-89.

- 2011a: Zaniklá středověká vesnice Roudnička - „Mořina“ pod Plešivcem (okr. Příbram) - Die mittelalterliche Dorfwüstung Roudnička - Lage „Mořina“ pod Plešivcem (Bezirk Př́íbram), AH 36, 387-394.

RBM: Regesta diplomatica nec non epistolaria Bohemiae et Moraviae VI. (Mendl, B., ed.). Praha 1928-1929.

RBM: Regesta diplomatica nec non epistolaria Bohemiae et Moraviae VII. (Mendl B.-Linhartová, M., edd.). Praha 1954-1963.

SMETÁNKA, Z., 1959: Středověká osada mezi Štíhlicemi a Kozojedy - Mittelalterliche Ansiedlung bei Kozojedy, AR XI, 683-691.

- 1961: Záchranný výzkum ve Štíhlicích u Českého Brodu - Rettungsforschung in Štíhlice bei Český Brod, AR XIII, 264-267.

SMETÁNKA, Z.-KLÁPŠTĚ, J., 1981: Geodeticko-topografický průzkum zaniklých středověkých vsí na Černokostelecku - Geodetical-topographical survey of deserted medieval villages in the Kostelec-nad-Černými-lesy region, PA LXXII, 416-458.

TENCER, T., 2017: Správa o geofyzikálnom prieskume. Brno.

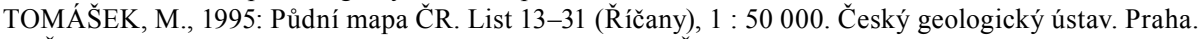

VAŘEKA, P., 2010: Zaniklá středověká vesnice Vojkov na Černokostelecku - nedestruktivní výzkum, Acta Filozofické fakulty ZČU, č. 4, 137-171.

ZÁDOROVÁ, T.-PENÍŽEK, V.-ŠEFRNA, L. et al. 2013: Identification of Neolithic to Modern erosionsedimentation phases using geochemical approach in a loess covered sub-catchment of South Moravia, Czech Republic, Geoderma 195-196, 56-69.

\section{Zusammenfassung}

\section{Jevany-Dubina - Revisionsuntersuchung einer mittelalterlichen Siedlungswüstung in der Region Kostelec nad Černými lesy}

Ziel des im Jahr 2016 an der Fundstätte Jevany-Dubina durchgeführten Untersuchungsprojektes war es, an ältere an der Fundstätte und in der gesamten Region Kostelec nad Černými lesy (Schwarzkosteletz) durchgeführten Grabungen anzuknüpfen. Zunächst wurden die im Siedlungsareal befindlichen Relikte vermessen und beschrieben, im Anschluss daran erfolgte eine geophysikalische Untersuchung und eine Interpretation. An der Fundstätte wurden ferner Feldbegehungen an den Stellen von illegalen Ausgrabungen durchgeführt, die eine genauere Datierung der Fundstätte ermöglichten. Ferner haben wir versucht, das wirtschaftliche Potenzial des Hinterlandes der Siedlung und die Möglichkeiten zu rekonstruieren, über die es verfügte.

In Kapitel 2 werden die natürlichen Bedingungen der Fundstätte beschrieben und die unzureichende Wasserversorgung hervorgehoben. Die Fundstätte wurde mit der sich in der Nähe befindlichen Dorfwüstung in der Lage Ve spáleném u Vyžlovky verglichen, die im Unterschied zu Jevany-Dubina und dessen kleinem Wasserreservoir über bis zu vier relativ große Reservoirs verfügte. Es ist wichtig anzuführen, dass die Besiedelung an beiden Fundstätten aufgegeben wurde und man die Gründe dafür den neuesten Erkenntnissen nach besonders auf die an den 
mittelalterlichen Fundstätten der Region Kostelec nad Černými lesy herrschenden ungünstigen hydrologischen Bedingungen zurückführen kann (Klápště 2016, 131).

Kapitel 3 beschreibt den Siedlungs- und eigentumsrechtlichen Kontext der Fundstätte im Rahmen der Region Kostelec nad Černými lesy. Die Existenz der Siedlung kann in den Zeitraum des 13. bis in die zweite Hälfte des 14. oder den Anfang des 15. Jahrhunderts gesetzt werden. Die Fundstätte ist nördlich von der Gemeinde Jevany gelegen. Die meisten Informationen hat bislang die im Jahr 1972 in ausgewählten Teilen der Fundstätte durchgeführte Rettungsgrabung geliefert, die sie auch grob datierte (Klápště 1978). Neu gefundene Keramikbruchstücke ergänzen die bisherige Datierung, die sich bisher lediglich auf die an Objekt 8 durchgeführte Grabung aus dem Jahr 1972 gestützt hat. Die Ergebnisse können wie folgt zusammengefasst werden: (1) die Fundstätte war bereits im ersten Siedlungshorizont der Region Kostelec nad Černými lesy besiedelt, der spätestens in der zweiten Hälfte des 13. Jahrhundert endet; (2) die Existenz der Siedlung überschreitet in keinem deutlicheren Maße die Zeit der zweiten Hälfte des 14. Jahrhunderts; (3) die Siedlung wurde mehr oder weniger in der gleichen Zeit wie die nahegelegenen Siedlungen Vyžlovka-Ve spáleném, Lažany und Štíhlice aufgegeben; (4) oberirdische Relikte müssen dem abschließenden Siedlungshorizont zugeordnet werden. Das muss nicht für die Ergebnisse der geophysikalischen Untersuchung gelten, durch welche mehrere voneinander nicht unterscheidbare Siedlungsphasen belegt wurden.

In den Kapiteln 4-5 wurden die auf der Fundstätte befindlichen Relikte im Hinblick auf ihre Funktion interpretiert (Abb. 5, Tab. 2). In rein sozialer Hinsicht entfallen auf die Siedlungswüstung zwei Varianten: (1) Lehnshof mit Unterkunft für einen Hintersass (Häusler), (2) kleine Ansiedlung mit zwei Untertanenanwesen. Im Diskussionskapitel 7 tendieren wir zur ersten Variante.

Kapitel 6 ist dem wirtschaftlichen Hinterland der Fundstätte und den Gründen für den Kollaps der landwirtschaftlichen Systeme gewidmet. Dabei sind wir von einer geringfügigen pedologischen Untersuchung in der Umgebung der Fundstätte ausgegangen. Zwei pedologische Sondierschnitte haben das Vorhandensein von Kambierde bestätigt, ein dritter Sondierschnitt wurde im Bereich der als Moklina bezeichneten Fläche gelegt, wo das Vorhandensein von Gleyen bestätigt wurde. Diese Böden sind für eine landwirtschaftliche Tätigkeit ungeeignet, man kann annehmen, dass sich in der Vergangenheit auf ihnen für das Weiden von Vieh geeignete Wiesen befanden. Die dort erkannte Bodenvariabilität musste in der Vergangenheit bei einer landwirtschaftlichen Nutzung der Landschaft berücksichtigt werden.

Der vorliegende Beitrag entstand im Rahmen des Projektes „Kulturtechniken: Materialität, Medialität und Imagination“ und des Unterprojektes „Das Dorf des Mittelalters und seine natürliche Umgebung“.

Interdisziplinäre Untersuchung von Dorfwüstungen im Prager Hinterland, realisiert an der Philosophischen Fakultät der Karls-Universität mit Mitteln der Spezifischen Hochschuluntersuchung für das Jahr 2018 (M. Janovský, J. Horák). Ferner wurde er vom Förderprojekt GA ČR Nr 16-20763S „Die Landschaft im mittelalterlichen Prag / The Landscape of Medieval Prague“ (T. Klír) gefördert.

Die Verfasser danken Herrn Jaroslav Batulek und Zvonimír Dragoun für die Hilfe bei der geodätischen Vermessung der Fundstelle sowie Herrn Prof. Jan Klápště für dessen ständige Konsultationen.

Mgr. Martin Janovský, Ústav pro archeologii Filozofické fakulty Univerzity Karlovy, Celetná 20, 11636 Praha 1; Katedra ekologie Fakulty životního prostředí České zemědělské univerzity v Praze, Kamýcká 129, 16500 Praha-Suchdol, Česká republika,janovskym@email.cz

Mgr. et Mgr. Jan Horák, Ph.D., Ústav pro archeologii Filozofické fakulty Univerzity Karlovy, Celetná 20, 11636 Praha 1; Katedra ekologie Fakulty životního prostředí České zemědělské univerzity v Praze, Kamýcká 129, 16500 Praha-Suchdol, Česká republika,jan_horak@email.cz

PhDr. Tomáš Klír, Ph.D., Ústav pro archeologii Filozofické fakulty Univerzity Karlovy, Celetná 20, 11636 Praha 1, Česká republika, tomas.klir@ff.cuni.cz 
